\title{
Correction to: A new species of the genus Xiphinema Cobb 1913 (Nematoda: Longidoridae) from north and Northwest Iran
}

\author{
Samira Fadakar • Ebrahim Pourjam • László Barsi • Majid Pedram
}

Published online: 12 April 2021

(C) Koninklijke Nederlandse Planteziektenkundige Vereniging 2021

\section{Correction to: Eur J Plant Pathol \\ https://doi.org/10.1007/s10658-021-02264-1}

Several author corrections were overlooked during proofing and have thus been corrected.

Original article has been updated.

The online version of the original article can be found at https://doi.org/10.1007/s10658-021-02264-1

S. Fadakar · E. Pourjam • M. Pedram $(\bowtie)$

Department of Plant Pathology, Faculty of Agriculture,

TarbiatModares University, Tehran, Iran

e-mail: majid.pedram@modares.ac.ir

L. Barsi

Faculty of Sciences, Department of Biology and Ecology, University of Novi Sad, Trg Dositeja Obradovića2, Novi

Sad 21000, Serbia 